\title{
Lived experience and the Holocaust: spaces, senses and emotions in Auschwitz
}

\author{
Nikolaus Wachsmann
}

Elie Kedourie Memorial Lecture, read 17 October 2018

\begin{abstract}
This article examines lived experience during the Holocaust, focusing on Auschwitz, the most lethal Nazi concentration camp. It draws on spatial history, as well as the history of senses and emotions, to explore subjective being in Auschwitz. The article suggests that a more explicit engagement with individual spaces_-prisoner bunks, barracks, latrines, crematoria, construction sites, SS offices - and their emotional and sensory dimension, can reveal elements of lived experience that have remained peripheral on the edges of historical visibility. Such an approach can deepen understanding of Auschwitz, by making the camp more recognisable and by contributing to wider historiographical debates about the nature of Nazi terror.
\end{abstract}

Keywords: Auschwitz, Holocaust, concentration camps, lived experience, spatial history, history of the senses, history of emotions.

Note on the author: Nikolaus Wachsmann is Professor for Modern European History at Birkbeck College (University of London), and has written extensively about repression and terror in the Third Reich. His most recent book is KL: A History of the Nazi Concentration Camps (2015, Farrar, Straus and Giroux), which won the Wolfson History Prize, the Mark Lynton History Prize and the Jewish-Quarterly Wingate Literary Prize.

(C) The author(s) 2021. This is an open access article licensed under a

Creative Commons Attribution-NonCommercial-NoDerivs 4.0 Unported License 
'Dear reader, I write these words in the moments of my greatest despair.' So begins a text by Zalmen Gradowski, composed in Auschwitz-Birkenau in spring 1944 and discovered after liberation, in a tin near the destroyed crematoria. Gradowski had been deported to Auschwitz from a transit camp near Grodno (Białystok district) in December 1942, as part of the Nazi regime's systematic extermination of European Jewry. His wife Sonia, his mother and two sisters were murdered within hours, together with hundreds of other Polish Jews on their train. Gradowski belonged to a much smaller group selected for slave labour, and the SS soon sent him to the dreaded Sonderkommando: prisoners forced to work at the gas chambers and crematoria. Until his own death in the camp, Gradowski secretly chronicled the never-ending procession of the doomed, from their tears as they undressed to their ashes being carted away on wheelbarrows. $\mathrm{He}$ hoped fervently that his writings would one day be found and help future generations to 'form an image' of the 'hell of Birkenau-Auschwitz'. Addressing his imaginary readers directly, he issued this appeal: 'It is for you to imagine the reality.'

Auschwitz has not been forgotten, as Gradowski had feared. As the single most lethal site of the Holocaust, where the SS murdered around one million Jews, it now occupies a central place in collective memory. But the Auschwitz of popular imagination often bears little relation to the Auschwitz Gradowski had lived and died in. As a global emblem of evil, the camp has become somewhat unmoored from its actuality. Popular images often float free of their historical context, gravitating towards myth and misconception, and distancing us from the crimes committed inside. ${ }^{2}$ It is often said, for example, that Auschwitz was a different planet, so alien that even birds did not sing here. ${ }^{3}$ But the camp was all too real, and so was the surrounding countryside. It was so rich in wildlife, in fact, that employees of IG Farben, the German firm that enslaved many thousands of prisoners, went birding together, while an expert ornithologist among the SS staff meticulously surveyed the local species for his scholarly publications. SS men even hunted ducks on the camp grounds. ${ }^{4}$ For prisoners, meanwhile, the familiar beauty of nature evoked agonising memories. Some months

${ }^{1}$ Gradowski (2017: 7-14, quotes on 10, 9); Kalisky (2019: 11, 20-1). For background, see also Chare \& Williams (2017: 60-92). The spelling of Gradowski's first name varies in the literature ('Zalmen'; 'Zalman'; 'Salmen').

${ }^{2}$ See also Didi-Huberman (2007b: 121-2).

${ }^{3}$ Charlesworth (2004: 222). See also Stone (2016: 47-9). The depiction of Auschwitz as another planet can be traced back to the survivor Yehiel Feiner (writing under the pen name Ka-Tzetnik); Bartov (2000: 185-212). References to the absence of birds already appeared in early survivor memoirs: for example, Szmaglewska (2008: 15).

${ }^{4}$ United States Holocaust Memorial Museum (USHMM), RG-11.001M.03, reel 70, 502-5-2, fol. 208: Betriebssportgemeinschaft an alle deutschen Gefolgschaftsmitglieder, 10 May 1944; Niethammer (1941, 1942); Zoologisches Forschungsmuseum Alexander Koenig, Historisches Archiv, G. Niethammer, 'Schussbuch für KL Auschwitz und Raisko'. 
before his murder in October 1944, Zalmen Gradowski wrote a lyrical lament about the moon; once a magical source of 'life and happiness' on the 'sky of freedom', it now impassively illuminated a place where 'every tree, every blade of grass is soaked with the blood of millions'. ${ }^{5}$

To meet Gradowski's appeal to 'imagine the reality' of Auschwitz, we must look at the living past, seeing the camp not as a symbolic place, but a historical one. ${ }^{6}$ Auschwitz as a historic site is far from terra incognita, of course. Many of its contours have been mapped by scholarly studies of the camp's organisation, the mechanics of mass murder and the practice of slave labour. ${ }^{7}$ Essential as these studies are, however, their conclusions have rarely reached a wider public, creating a gulf between specialist knowledge and public beliefs. ${ }^{8}$ One cause for this disconnect is that the camp depicted in academic works often appears impersonal and inanimate, leaving plenty of room for less authoritative accounts to produce popular myths, such as the vision of Auschwitz as a highly automated 'factory of death', based on an immutable blueprint and operated by hyperefficient guards, who killed a uniform mass of passive, benumbed victims.

How to make Auschwitz more recognisable? Lifting individual faces from the crowd, as historians sometimes do, personalises the nameless horror and makes victims and perpetrators more visible as human beings. But we should go beyond such external descriptions and explore the subjective being in Auschwitz. We need to look more closely at the lived experience of prisoners, perpetrators and onlookers, uncovering their perceptions of the everyday and the meanings they attached to them. ${ }^{9}$ Such a focus on lived experience, which has gradually been applied to other aspects of the Nazi dictatorship, can help us form a deeper understanding of Auschwitz. ${ }^{10}$ Revealing the textures of everyday life - the ordinary in the extraordinary - can demystify Auschwitz and render it more palpable. It moves the spotlight from the camp as a remote monument to suffering, standing almost outside time, to the reality of living and dying in Auschwitz. It also sheds light on agency and accentuates contrasts between individual actors; for no one experienced Auschwitz in the same way. Finally, it imbues static images with immediacy. Auschwitz was all flux and motion, contingency and change, challenging assumptions that the camp followed a straight, predetermined path into the abyss.

\footnotetext{
${ }^{5}$ Gradowski (2017: 69-76, quotes on 70-1). See also Chare \& Williams (2017: 71-4). Historians estimate that at least 1.1 million men, women and children perished in the Auschwitz complex; Piper (1993: 167). ${ }^{6}$ The term 'living past' is used in R.G. Collingwood's reflections on history and experience; Jay (2005: 235).

${ }^{7}$ Extensive historical surveys include Gutman \& Berenbaum (1998); Długoborski \& Piper (2000).

${ }^{8}$ More generally on this gulf: Hayes (2017: 327).

${ }^{9}$ On experience as process and product, Pickering (1997: 92-6). See also Geertz (1986: 374).

${ }^{10}$ For the initial resistance of structuralist historians to 'the recapturing of subjective historical experience' in the Third Reich: Jay (1989: 31-4).
} 
'Experience' is a foundational concept for historians, though far from a straightforward one. ${ }^{11}$ After all, we cannot fully recover past experience and somehow recreate how Auschwitz felt; to suggest otherwise would be 'naïve empathy'. ${ }^{12}$ All we can do is examine how individual experience was expressed, and investigate how it may have been shaped by specific cultural settings and social situations. ${ }^{13}$ This requires a close reading of contemporary documents and later testimonies, and their careful contextualisation.

So abundant are the traces of lived experience in the sources, we need to filter them, magnifying some facets to bring them into sharper relief. To do so, this paper will look at Auschwitz through the lenses of space, sense and emotion, all of them essential components of individual experience. Combining these three perspectives, the paper will move through a succession of spaces to reveal different aspects of sense and emotion in Auschwitz. Specific spaces evoke specific emotions, after all, and are demarcated by specific smells, sounds, sights and textures.

The usefulness of spatial approaches to Holocaust studies has been demonstrated by recent research on local and regional dimensions of genocide, and the destructive bio- and geopolitical dreams of Nazi planners behind it. ${ }^{14}$ Inter alia, these studies have directed our attention to long-forgotten camps and ghettos in German-occupied eastern Europe, and to the forests, fields and ravines where mobile killings squads mowed down many hundreds of thousands of Jewish men, women and children. Pioneering scholars have also drawn on historical geography, conflict archaeology and Geographic Information Science, in order to examine the material landscape of persecution and to map sites of Nazi mass murder. ${ }^{15}$ Such spatial approaches can enrich our understanding of lived experience in Auschwitz, too, with the most significant impulses so far coming from architectural history. ${ }^{16}$

\footnotetext{
${ }^{11}$ Mah (2008: 97). For historians and 'experience', see also Samuel (2016) and the historiographical survey in Jay (2005: 245-55). For a broader theoretical approach: Lash (2018).

${ }^{12}$ For the term: Pickering (1997: 137). In memoirs, survivors also reflect on the difficulty of recapturing what they had felt many years earlier in Auschwitz: for example, Bornstein (2015: xxii-xxiii).

${ }^{13}$ For the pioneering work of cultural anthropologists on 'experience': Bruner (1986).

${ }^{14}$ For a recent survey of regional Holocaust studies: Lower (2018). For pioneering research into Nazi plans for the racial reordering of eastern Europe: Aly \& Heim (1993); Roth (1993). For the 'bio-geopolitical' nexus in the Third Reich, Giaccaria \& Minca (2016b: 29).

${ }^{15}$ Carr et al. (2018); Cole (2003); Knowles et al. (2014); Sturdy Colls (2015).

${ }^{16}$ Pioneering studies include Dwork \& van Pelt (1997); Gutschow (2001). More recently, Citroen \& Starzyńska (2011); Greif \& Siebers (2016); Jaskot (2017). See also the series 'The Architecture of Crime', published by the Auschwitz-Birkenau State Museum. Architectural approaches extend beyond the academy. The 2016 Venice Architecture Biennale featured plaster reconstructions of parts of the Birkenau gas chambers, while the Bavarian police has built a virtual reality model of the camp to aid criminal investigations: Bernstein (2016); Schuessler (2016). More generally on spatial approaches to the Nazi camps: Klei et al. (2011).
} 
By contrast, Holocaust historians have been slow to engage with the rise of sensory studies, sceptical, perhaps, whether it could tell us anything new. ${ }^{17}$ Sensory history explores the significance and meaning of sensory experiences in specific historical contexts, examining how they shaped past cultures. Instead of privileging vision, which has dominated Western models of human perception, it examines the role of all senses, and their complex interaction in a 'web of sensory relations'. ${ }^{18}$ Such a multisensory approach should also guide an examination of lived experience in Auschwitz. Remembering a piece of bacon flatbread she received from a fellow inmate in 1944, the Italian survivor Liana Millu recalled that she ate not just with her mouth, but also 'with the nose, the eyes, the hands, all senses relished this gift', creating an overwhelming feeling of joy. ${ }^{19}$

Feelings like pleasure, as well as pain and fear, have become focal points of recent histories of the emotions, attracting sustained scholarly attention after long years on the sidelines. This research is driven by an interest in subjective experiences of the past, as well as the relation between individuals and society, with historians exploring the social conditioning of emotions, their meaning and expression, and their place in social and political action. As Ute Frevert memorably put it: 'feelings make history'. ${ }^{20}$ Studies of the Holocaust have touched on the emotions, too - euphoria and hatred of Nazi leaders and killers; despair, trauma and false hope of Jewish victims; tenderness and tensions between prisoners; indifference and greed of German onlookers-but overall, such references have been rather cursory and incidental. ${ }^{21}$ As this article will show, a more explicit engagement with emotions, and their spatial and sensory dimension, can bring out elements of lived experience in Auschwitz that have so far remained peripheral on the edges of historical visibility. ${ }^{22}$

\footnotetext{
${ }^{17}$ On the emergence of sensory studies more generally: Bull et al. (2006).

${ }^{18}$ Quote in Howes (2008: 448). See also: Classen (1993: 1-11, 2012: xi-xii); Cornish et al. (2017); Jütte (2005: 8-17). For a definition of 'sensory history': Smith (2007: 4-5).

${ }^{19}$ Millu (1999: 140).

${ }^{20}$ Frevert (2009: 202). For an overview: Plamper (2017: 40-74, 251-96). Shorter introductions include Rosenwein $(2002,2010)$. Interest is the history of emotions is reflected in recent work on the everyday lives of ordinary Germans in the Third Reich, from expressions of love for Hitler to fears of Allied bombs: Przyrembel (2018); Süss (2014). More generally: Forum (2010).

${ }^{21}$ Aly (2007); Browning (2004: 309-30); Confino (2014: 183-232); Friedländer (2007, 2009); Goldberg (2017); Goldhagen (1996); Kershaw (2002: 358-72); Pingel (1978). The most sustained scholarly work has examined the trauma of survivors: Eitinger (1985).

${ }^{22}$ For a pioneering study of genocide and the emotions: Brudholm \& Lang (2018).
} 


\section{Natural and built environments}

Following the German invasion of Poland in autumn 1939, which marked the beginning of the Second World War, SS officers soon scouted locations for a new concentration camp to help repress the Polish population and destroy the resistance. During the early months of 1940, they settled on Oświęcim, a town in eastern Upper Silesia, renamed Auschwitz by the occupiers. They were attracted by its good transport links and a large barrack compound on the outskirts, originally built for seasonal workers, which formed the initial core of the new site (the main camp). In their mind, these infrastructural benefits outweighed obvious environmental problems, such as the waterlogged ground prone to flooding. ${ }^{23}$ Over the coming years, SS staff and German civilians would often grumble about their working conditions-the poor water supply and sewage system, the plague of insects and infections - which they blamed, in their colonial mindset, on the 'lowest levels of civilisation and culture' in this 'formerly Galician territory', in the words of two senior IG Farben employees. ${ }^{24}$

What was a nuisance to the occupiers posed an existential threat to prisoners weakened by SS abuse. Starved and sick, they saw the natural world as yet another adversary. The local climate, one survivor wrote in 1945, acted 'as if in cahoots with the barbarians'. ${ }^{25}$ Early in the mornings, anxious inmates would check on the unpredictable weather, as each season brought its own torment. ${ }^{26}$ In spring and autumn, heavy rains and strong winds drenched those toiling outside, spreading disease and death. A sea of mud covered much of the ground, clinging like a living organism to tired feet and tattered clothes, encroaching even on prisoner dreams. 'When it rains we would like to cry', Primo Levi later wrote. ${ }^{27}$ After the soil had dried in the summer sun, stretches of the camp turned desolate and dusty, giving it an almost desert-like sheen. Humid heat bore down on thirsty, sweating and sunburned inmates, who suffered more than ever from bugs and mosquitoes. ${ }^{28}$ But prisoners also feared the cold.

\footnotetext{
${ }^{23}$ Steinbacher (2000: 28, 66-7, 178-9); Dwork \& van Pelt (1997: 58-9, 166-8, 191). See also USHMM, RG-11.001M.03, reel 32, 502-1-192, Erläuterungsbericht, 19 November 1940; Bundesarchiv Berlin, NS 19/1919, fol. 25-7: Glücks to Himmler, 21 February 1940.

${ }^{24}$ Quote in Auschwitz-Birkenau State Museum Archives (APMO), IG Farben, t.1, Werk Auschwitz to Dr. Krauch, 25 October 1941. See also: Bezwińska \& Czech (1981: 211-7); Steinbacher (2005: 73).

${ }^{25}$ Instytut Pamięci Narodowej, GK 182/155, testimony A. Górski, 10 February 1945 (translation at www. zapisyterroru.pl; accessed 5 November 2020).

${ }^{26}$ On the Auschwitz weather in general, from the perspective of survivors: Frankenthal (2002: 49); Sachnowitz (1981: 33, 43-4).

${ }^{27}$ Levi (1987: 137). See also Delbo (1995: 54-5); Shelley (1992: 79); Sonnino (2006: 80-1); Zywulska (2011: 68-9). For an analysis of mud in Birkenau: Cole (2016: 92-4).

${ }^{28}$ Frei et al. (2000: 464); Nyiszli (2012: 1); Szmaglewska (2008: 184).
} 
Thin uniforms and cheap barracks afforded little protection against icy gusts and snow. Winter, the prisoners knew, was the season of frostbite and amputations. ${ }^{29}$

While inmates were largely at the mercy of the SS and the elements, there was some room, however small, for their agency. Prisoners drank from rain puddles and ate snow to quench their thirst, for example, and used snow and rain to clean themselves. ${ }^{30}$ They also sought, as best they could, to work in more sheltered places or indoors, aware that this could make the difference between life and death. The SS, meanwhile, was busy remaking the landscape, using slave labour. Soon, drainage ditches, sludge pools and artificial ponds pockmarked the camp area. Grass, trees and flowers were planted to beautify SS offices and conceal SS crimes, while the ashes of murdered Jews were later dumped into a nearby river, drifting downstream to feed the fish, as the guards joked. ${ }^{31}$

All the changes to the natural landscape were accompanied by a sweeping transformation of the built environment. The buildings and ruins, and eight miles of fencing, that make up the Auschwitz-Birkenau memorial today are concrete remains of what once was a vast city of terror. In addition to the prisoner compounds, there had been workshops and warehouses, garages and laundries, laboratories and infirmaries, bakeries and an abattoir; the local SS settlement even had its own kindergarten. These places were located within the SS-controlled 'interest zone', spread over some 15 square miles, which included the dark heart of the complex-the main camp and the Birkenau extension, less than two miles apart — as well as a few smaller satellite camps. Outside, on the periphery, lay around three dozen more satellite camps, often near mines and factory grounds; the largest was Monowitz, where prisoners toiled for IG Farben. ${ }^{32}$

Visitors to the Auschwitz memorial today find the site still and static. To imagine the past, they must unfreeze it and visualise a place in perpetual motion. SS men on bikes, motorcycles and in cars crossed the complex at all times. Inmates were constantly on the move, too, pulling carts, marching to work, staggering to infirmaries. Day and night, trains and motor vehicles brought new arrivals, dazed and exhausted, from other places of repression or moved inmates from one Auschwitz site to another. At the height of the Holocaust in Auschwitz in spring and summer 1944, as many as 16,000 Jews arrived daily in Birkenau. The dense network of Birkenau camp streets, more than six miles in length, was often packed as a result: new arrivals were hurried

\footnotetext{
${ }^{29}$ Herrmann (1994: 50); Millu (1999: 80); Piper (1970: 71-2).

${ }^{30}$ Delbo (1995: 27); Hamburger Institut (1994: I, 187); Shelley (1991: 160).

${ }^{31}$ Charlesworth (2004: 223); Greif (1995: 145); Greif \& Siebers (2016: 147-9, 184-5).

${ }^{32}$ For the figures: Greif \& Siebers (2016: 14); Megargee (2009, 1/A: 221-75); Strzelecka \& Setkiewicz (2000: 72-3, 80). More generally: Sofsky (1997: 63); Steinbacher (2000: 182-9). On the centre-periphery model: Rau (2017: 147-8).
} 
towards baths, barracks or gas chambers, while SS trucks drove the old and weak to their deaths, and their property to storage areas; Sonderkommando prisoners like Zalmen Gradowski, stationed by the crematoria, knew that more victims were on their way when they heard the 'well-known rumble of the truck wheels'. At the same time, prisoner transports also regularly departed from the Auschwitz complex, especially in the final months and weeks when the SS prepared to evacuate the complex before the advancing Soviet forces. ${ }^{33}$ Then there was the constant flow of goods. The SS received countless deliveries, from building materials to poison gas, and dispatched myriad items, from prisoner-made military supplies to the belongings of murdered Jews; towards the end, the SS even shipped out parts of the crematoria, planning to reuse them elsewhere. ${ }^{34}$

The camp, then, was always in flux. This was true for people and goods, and also for the spaces they traversed. Because the Auschwitz complex was one big construction site, and never looked the same from one day to the next. SS construction has often been overlooked, despite the wealth of surviving documents and the profound impact of building work on prisoner experiences: many prisoners paid with their blood and their lives, their bodies beaten and broken as they dug foundations, mixed cement and hauled bricks. ${ }^{35}$ Early on, the SS oversaw demolition work on the camp grounds and further afield, to create a more secure boundary and reclaim supplies, such as bricks and paving stones. The SS also extended and adapted existing structures; in the main camp, one-story buildings were raised to cram more prisoners inside, increasing the site's density, while an old ammunitions bunker was turned into the first crematorium. ${ }^{36}$

Most importantly, the SS constructed hundreds of new structures, including barracks, stables and factory halls. Entire subcamps were erected from scratch, among them Monowitz and Birkenau. As late as September 1944, just a few months before liberation, the Camp SS held a grand ceremony to unveil a brand-new staff hospital spread across several tree-lined buildings, including a well-equipped dental clinic and

\footnotetext{
${ }^{33}$ Quote in Gradowski (2017: 148). For prisoner transports: Czech (1989). For deportations from Hungary: Aly \& Gerlach (2002: 296-7). For streets in Birkenau: Piper (1995: 151). The sounds of trucks, trains and cars was a daily part of the Auschwitz soundscape, qualifying the assumption that 'the aural environment' of Jews persecuted during the Holocaust was 'stunningly empty of noise generated by machines': Gerlach (2018:1).

${ }^{34}$ For the crematoria: Perz \& Freund (2004). More generally on movement, mobility and space: Cresswell (2006: 1-6).

${ }^{35}$ Jaskot (2017: 2); Jaskot et al. (2014: 185). So far, the attention of historians interested in the built environment of Auschwitz has focused, understandably, on the apparatus of mass murder: Pressac (1995); van Pelt (2002).

${ }^{36}$ Strzelecka \& Setkiewicz (2000). For the crematorium, see also Dwork \& van Pelt (1997: 176-7).
} 
bright neonatal unit. ${ }^{37}$ This project was led by the SS Central Construction Authority in Auschwitz, which controlled building matters across the complex. In all, more than 180 staff worked here, as did hundreds of prisoner clerks, designing everything from hinges and doorknobs to whole compounds; the building work itself was carried out by private contractors, civilians and slave labourers. ${ }^{38}$ One of the busiest periods came in spring 1943, when more than 70 new structures were being built in Birkenau alone, including four crematoria. During an inspection by a leading SS manager that April, the head of the Central Construction Authority, Sturmbannführer Karl Bischoff, proudly pointed to the size and scope of the 'extremely extensive building activity in the local interest zone'. ${ }^{39}$

Once completed, new buildings entered the fabric of everyday life. The crematoria, for example, served as unremitting reminders of what awaited many prisoners registered for slave labour. Construction was not just about securing SS dominance, however. Inadvertently, it also created spaces for prisoner agency. The more civilian contractors worked on site, the greater the inmates' opportunity for barter and bribes. ${ }^{40}$ All the clutter and commotion also made it harder for the SS to exercise full control, as blocked sightlines opened the way for banned activities. ${ }^{41}$ Crucially, these were not the only areas where SS plans and practices failed to align.

\section{Imagined spaces}

Nazi leaders saw the invasion of Poland, and later the Soviet Union, as a historic opportunity to settle German 'living space'. The future of the nation depended on settlements in the east, they believed, and forging this German space meant eradicating Jews and other 'racial aliens'. In pursuit of this destructive dream, they brought slave labour, ethnic cleansing and genocide to occupied eastern Europe. ${ }^{42}$ Radical racial colonialism transformed Auschwitz. The first Camp SS men, arriving in 1940, still considered the town as a primitive backwater in the Polish provinces. ${ }^{43}$ But it already stood on German soil, having been incorporated into Upper Silesia after the invasion, and before long, the town was designated as a model settlement. Local Jews

\footnotetext{
${ }^{37}$ USHMM, photo archives, images 69181, 69184, 69263, 69271, 69271D; Busch et al. (2016: 263-92).

${ }^{38}$ Fröbe (2000).

${ }^{39}$ Quote in USHMM, RG-11.001 M.03, reel 20, 502-1-26, fol. 68-71: Niederschrift über die Besprechung mit SS-Gruppenführer Frank, 23 April 1943. For the figures: Jaskot et al. (2014: 181).

${ }^{40}$ For one example: Strzelecka (2002: 217).

${ }^{41}$ Jaskot et al. (2014: 181-2).

${ }^{42}$ Lower (2012); Neumann (2010: 62-76).

${ }^{43}$ Нӧß (1994: 134-5).
} 
and many Poles were evicted or deported, and thousands of German nationals moved in. Town planners reimagined the place, aiming to turn a 'piece of desolate earth' into a 'true cultural landscape', as the architect in charge put it. He pictured grand new districts, with modern amenities and monumental party buildings, and a luxury hotel on the grounds of the Jewish cemetery. ${ }^{44}$

Colonial fantasies also shaped the adjacent camp complex. To help cultivate 'living space', agricultural research was undertaken in several Auschwitz satellite camps. ${ }^{45}$ And after the invasion of the USSR, SS leader Heinrich Himmler ordered the enslavement of hundreds of thousands Soviet POWs for a gargantuan SS building programme to 'make the east German', with Auschwitz assigned a significant part in his plans. In October 1941, the SS commenced the construction of the Birkenau extension, designed as a giant slave labour hub for Soviet soldiers. But Himmler's dream never materialised: far fewer POWs arrived than expected, and most who did soon died, prompting the SS to reconceive Birkenau as a camp for other prisoner groups, above all Jews, though now less with an eye on German settlements. ${ }^{46}$

Some scholars see concentration camps as sites of total SS domination. ${ }^{47}$ This was certainly what the perpetrators wanted them to be, and their monumental designs for Auschwitz reflect an absolute belief in the might and right of the SS. The plans included a huge new command centre, complete with ceremonial hall; a sprawling garden city with leisure facilities for SS staff and their families; and the vast Birkenau compound, projected for up to 200,000 prisoners. ${ }^{48}$ But these designs often bore little resemblance to built reality. Birkenau, for example, was under permanent construction and never completed, as priorities changed, again and again, and planners were thwarted by supply shortages, bad weather, reversals in the war, epidemics and - most critically — by mass deaths among their slave labour force. In practice, grand visions often gave way to quick fixes, resulting in the 'lack of a rationally planned and controlled space'. ${ }^{49}$ Auschwitz, like the rest of the Nazi dictatorship, was not a straight-line, single-track totalitarian machine.

The ensuing chaos and improvisation led to the continual repurposing of space. The main camp, for instance, originally encompassed three brick buildings (Block Nos 1-3) in the most easterly corner of the old barrack compound, which were fenced

\footnotetext{
${ }^{44}$ Quote in Dwork \& van Pelt (1997: 250). For an overview: Steinbacher (2005: 62-78). More generally on 'imagined spaces': Rau (2017: 94-5, 150).

${ }^{45}$ Kaienburg (2003: 840-55).

${ }^{46}$ Wachsmann (2015: 274-87, quote on 276). See also Schulte (2001: 259-78, 332-56).

${ }^{47}$ Arendt (1976); Sofsky (1997).

${ }^{48}$ Czech (1989: 275); Dwork \& van Pelt (1997: 225-30, 252-3).

${ }^{49}$ Jaskot (2017: 14), 'lack' italicised in the original. See also ibid., 17. For continual construction in Birkenau: Jaskot et al. (2014).
} 
off in spring/summer 1940. As more prisoners arrived, this area was successively enlarged to encompass more buildings. Then, in autumn 1941, when the local SS learned about the imminent influx of Soviet POWs, it hastily split the whole site in two, putting barbed wire around nine blocks on the northern part (Nos 1-3, 12-14, 22-24) to create a makeshift camp within the camp. Some 10,000 Soviet soldiers were forced into this new POW compound in October 1941. Less than six months later, the compound stood empty again, after more than 9,000 POWs had perished and the survivors were transferred to the first barracks in Birkenau. The main camp did not revert to its previous appearance, however. The Auschwitz SS already expected further mass transports, this time of women (mostly Jewish), and scrambled to establish a space to hold the first female prisoners. Hectic activity led to the creation of another camp within the camp, this time enclosing ten blocks (Nos 1-10) along the eastern perimeter with a concrete wall. The first women arrived here in late March 1942, and many thousands had followed them by August, when the SS moved the surviving women to Birkenau and began to dismantle the recently erected concrete panels. In just two years, then, the first three blocks of the main camp had held, in succession, male Polish political prisoners, Soviet soldiers and Jewish women, revealing the ad hoc nature of SS zoning. ${ }^{50}$

\section{Boundaries}

Auschwitz was not a single camp, occupying one continuous, homogeneous zone. It was a large, sprawling conglomerate of subcamps and sectors, separated by visible and invisible boundaries. Conditions for prisoners differed sharply, depending on where they were held, not just in terms of treatment, daily routines and slave labour, but also in regard to the material landscape. One has to look no further than the contrast between the main camp and Birkenau to recognise profound differences in the built environment. In the former, most prisoners lived in brick barracks with windows, solid floors and running water. In the latter, prisoners were often forced into rickety, windowless horse stables built on marshy soil, with leaking roofs, porous wooden walls and muddy floors, where they suffered from a chronic lack of drinking water that left many mouths too dry to speak or eat. The entire sensory landscape was different, especially after the SS began to operate the new crematoria in Birkenau and abandoned the main camp crematorium. Although few prisoners could observe these new buildings directly, they were ever-present. Inmates saw dark smoke rising during

${ }^{50}$ Greif \& Siebers (2016: 72-4); Lachendro (2016: 14-20); Setkiewicz (2008: 15-25); Strzelecka \& Setkiewicz (2000: 66-79). I am using the block numbering as it appears at the memorial today. 
the day, so thick it sometimes obscured the sun. When it got dark, they saw a fierce red glow, like a house was on fire, which clouded the stars above on clear nights. They smelled the burning flesh, which clung to their mouths and throats, especially when the wind blew from the west. Sometimes they even heard the cries of the doomed. No wonder that prisoners in the main camp feared transfers to Birkenau, where death was omnipresent, and thirst, dirt and disease were so much worse. ${ }^{51}$

For all of the impromptu elements of SS zoning, the spatial distribution of prisoners across the different parts of the Auschwitz complex was not accidental. The SS was intent on separating registered inmates according to criteria like prisoner category, health, gender and ethnicity. Male Polish political prisoners were far more likely to be isolated in the main camp than in Birkenau, for example, while the reverse was true for Jews and for Sinti and Roma. ${ }^{52}$ Given that living conditions in Birkenau were far worse than in the main camp, one could be led to conclude that this allocation simply reflected SS racial hierarchies, with prisoners at the bottom forced into the most lethal spaces. But practical considerations were part of the SS equation too. Male political prisoners from Poland constituted the bulk of the inmate population early on and were already installed in the main camp when new inmate groups arrived - including 'racial aliens' like Jews, but also female political prisoners from Poland and elsewhere-prompting the SS to direct them to the still-empty extension in Birkenau. ${ }^{53}$

Not only were there huge disparities between the camps that constituted the Auschwitz complex, there were sharp differences within individual camps, depending on the specific sector prisoners found themselves in. In early summer 1944, Birkenau alone contained around a dozen fenced-off sectors for different prisoner groups: slave labourers were separated from the sick, recent arrivals from veterans, registered inmates from newcomers selected for the gas chambers, and men from women (though there were also two family compounds, for Sinti and Roma, and for Jews deported from the Theresienstadt ghetto)..$^{54}$ Each sector had its own characteristics and materiality, with major implications for prisoner lives. For example, women in the oldest Birkenau sector (BI) lived in a mix of wooden and brick barracks, with some basic furniture and access to primitive washrooms and latrines, while women in the

\footnotetext{
${ }^{51}$ Adelsberger (2005: 73-4, 88-9); Cole (2016: 92-4); Delbo (1995: 142-5); Gross \& Renz (2013: 620); Hamburger Institut (1994: I, 192); Klüger (1992: 118); Langbein (1995: 710-11); Setkiewicz (2018a: 61); Siedlecki et al. (2000: 118-21); Sobolewicz (1993: 137); Świebocka (2001: 119); Szmaglewska (2008: 30). ${ }^{52}$ Setkiewicz (2018b: 37).

${ }^{53}$ After the 1944 Warsaw uprising, the SS also directed many male Polish political prisoners to Birkenau: Kubica (2015: 18-23).

${ }^{54}$ Birkenau map in Greif \& Siebers (2016: 156-8). See also Cole (2016: 75-81). Several of these Birkenau sectors were multifunctional. For example, the Birkenau hospital compound for men (BIIf) functioned as a site for basic care, human experiments, killing, and selection for the gas chambers.
} 
most recent Birkenau sector (BIII) were forced to sleep on the naked ground in barren wooden barracks that lacked any amenities whatsoever. ${ }^{55}$

Rigid SS rules governed prisoner activities, dictating when they had to be where, and most inmates were barred from crossing boundaries into different sectors. Consequently, they could only gain limited insights into other parts of the camp. Walter Winter, a German Sinto, never moved far from the 'Gypsy' sector (BIIe) during his time in Birkenau. It was only when he returned to the memorial, over forty years later, that he realised 'for the first time, the size of the camp' ${ }^{56}$ Only the privileged few could enter sectors other than their own. Among them were prisoner clerks from the camp administration and specialist tradesmen, like Mordechai Ciechanower, who gained access to various Birkenau sectors, as well as the SS guard towers, as a member of the roof repair commando. ${ }^{57}$ But even privileged prisoners like him had their movements strictly restricted. When the prisoner scribe Tadeusz Joachimowski was caught one day by SS officers, as he took a shortcut across the grounds of crematoria IV and $\mathrm{V}$, he fully expected to die. 'Anyone who ever entered this space', he recalled, 'had no right to leave it again.' ${ }^{58}$

Although the different prisoner sectors were created by the SS, the authorities were never in complete control over these social spaces, as prisoners developed 'spatial strategies of survival'. ${ }^{59}$ Some used their knowledge of the local topography to escape; in an exceptional case, two prisoners from the Sonderkommando disappeared into nearby woods under the cover of the thick smoke emanating from the crematoria. ${ }^{60}$ Far more often, prisoner 'practices of everyday life' made SS spaces their own. ${ }^{61}$ Despite all their suffering and fears, not all inmates were suspended in a state of complete helplessness. ${ }^{62}$ Prisoners actively established illicit places to talk, pray, cook and barter, and even to get drunk; after hauling bodies to the main camp crematorium, prisoners from the corpse carrier commando would sometimes gather in the autopsy room, unobserved, and drink a heady mix reeking of petrol and formaldehyde. ${ }^{63}$

\footnotetext{
${ }^{55}$ Strzelecka \& Setkiewicz (2000: 86-9, 98-9).

${ }^{56}$ Winter (2004: 53).

${ }^{57}$ Ciechanower (2015: 117, 122).

${ }^{58}$ Hessisches Hauptstaatsarchiv Wiesbaden (= HHStAW), Fonds 461, Nr. 37976/30, fol. 87-99: Zeugenvernehmung T. Joachimowski, 19 October 1966, quote on 99.

${ }^{59}$ Cole (2016: 4). For the term 'social space': Bourdieu (1989).

${ }^{60}$ Broad (1981: 167); Giaccaria \& Minca (2011: 10).

${ }^{61}$ For the term and concept: De Certeau (1988). On spatial dynamics more generally: Rau (2017: 164-72).

${ }^{62}$ For the argument that Jewish victims experienced 'radical helplessness' during the Holocaust: Goldberg (2017: vii-7).

${ }^{63}$ Kielar (1979: 86-8).
} 
Such activities were possible because the Auschwitz SS did not perfect the disciplinary ideal of continual surveillance. For all its dominance, the Camp SS was not all-seeing, as has sometimes been suggested. ${ }^{64}$ Many SS staff actually avoided close encounters with inmates, fearing attacks and infectious diseases like typhus. The fences around the different sectors were not just meant to prevent escapes, they also kept prisoners at a distance from the staff, illustrating how SS fears shaped social space in Auschwitz. It was no coincidence that the huts of SS block leaders, who oversaw individual compounds in Birkenau, stood outside the barbed wire. ${ }^{65}$

In addition to boundaries separating SS and prisoners, there were also boundaries between SS staff. Different spaces were reserved for different officials, based on rank, gender and function. SS officers often occupied houses and villas seized from local Poles, for example, while most of the rank-and-file shared dormitories in large barracks. When they were at work, men on sentry duty would not normally enter the prisoner sectors. This was the prerogative of commandant staff members, and even they required authorisation for accessing individual compounds. Among the most secluded places were the gas chambers and crematoria at the far end of Birkenau. Cordoned off from other zones, they were staffed by a small group of SS experts in mass murder and cremation. Just like the uniformed German executioners who pulled the trigger on the killing fields, these men typically saw themselves as the toughest among their peers, unflinching and indomitable. Female guards, often derided by their male colleagues as weak and hysterical, were excluded on principle; the Birkenau zones of death were hypermasculine SS spaces. ${ }^{66}$

Obviously, the most critical border was the one separating the camp complex from the outside world. Prisoners often thought about what lay beyond, about their earlier lives and their loved ones. But releases were rare and successful escapes even rarer. Auschwitz was 'a German concentration camp', Obersturmführer Karl Fritzsch had lectured the first Polish prisoners in June 1940, with 'no exit except through the chimney of the crematorium'. ${ }^{67}$ This did not mean, however, that prisoners would never leave the camp grounds, and in practice, the borders around the complex proved far more flexible than solid. ${ }^{68}$ True, the compounds were enclosed by wires, fences and towers. But most prisoners only spent their nights inside. During the day, they moved outside for slave labour. Armed sentries accompanied these commandos, their precise

\footnotetext{
${ }^{64}$ For the depiction of Auschwitz as a typical panopticon: Charlesworth (2004: 227); Sofsky (1997: 64). For background: Jaskot et al. (2014: 181-2).

${ }^{65}$ On the relation between emotions and the production of spaces: Gammerl \& Herrn (2015).

${ }^{66}$ Wachsmann (2015: 108, 364-9). More generally: Browning (1996: 241-2); Hördler (2015: 108-77).

${ }^{67}$ Quote in Strzelecka (1990: 27, footnote 22). On escapes: Świebocki (2000: 191-235).

${ }^{68}$ For the opposite view: Sofsky (1997: 70-2).
} 
position and posture prescribed by SS rules (there was even a manual with crude cartoons to remind them). Other SS men were stationed at guard posts, forming large sentry chains around parts of the SS 'interest zone'; the cordon around the main camp had a circumference of five miles or more. In the evenings, after labour commandos returned to the compounds, the large sentry chains were pulled back again. In this way, the Auschwitz camp borders extended and contracted daily. ${ }^{69}$

For the SS, the boundary around the camp was not just about controlling prisoners, it was also about controlling the flow of goods and knowledge. But the SS did not succeed in hermetically sealing off camps like Auschwitz, as has sometimes been argued. ${ }^{70}$ The practice of outside labour made it more porous, creating spaces for the clandestine interaction between prisoners and locals. Polish civilians engaged in various spontaneous and organised acts of resistance. 'On several occasions while reaping the grain', the survivor Adam Jurkiewicz remembered, 'we came across little bundles left in the fields, containing bread with lard or marmalade. ${ }^{71}$ Polish civilian resisters did more than provide food and medicine. They also smuggled letters between prisoners and their relatives, and gathered information about the terror in the camp. News about SS crimes in Auschwitz were also transmitted by others: SS wives, IG Farben employees, railway workers, German policemen. ${ }^{72}$ Rumours spread through the nearby town, as did some of the evidence. No fence could stop strong winds from blowing rotten fumes from Birkenau to the local railway station and the streets beyond. One day, sometime after her relocation from Berlin to Auschwitz, a German teacher returned home from the town's high school to find her desk covered in what looked like cigar ash. Her landlady explained that this was 'human ash' from the camp, where they were 'again burning some in the crematorium'. ${ }^{73}$

\section{Sensing Auschwitz}

The materiality of mass murder - the stench, the smoke, the cremated remainshighlights once more the role of the senses in Auschwitz. For the prisoners, their very survival depended on the ability to react quickly to external surroundings, and some

\footnotetext{
${ }^{69}$ Setkiewicz (2008: 48-51); Strzelecka \& Setkiewicz (2000: 72); APMO, Proces Maurer, 5a, fol. 126-41: Bilderbuch 'Falsch-Richtig' für die Posten im KL-Dienst. For a prisoner perspective: Siedlecki et al. (2000: 163-5).

${ }^{70}$ For this view: Neumann (2010: 100); Sofsky (1997: 70-2).

${ }^{71}$ Świebocki (2000: 154-71, quote on 155).

${ }^{72}$ Dörner (2007: 39); Steinbacher (2000: 187-8, 247-9).

${ }^{73}$ Deutsches Tagebucharchiv, Reg. 463/Sig. 398, quote on p. 20. See also: HHStAW, Fonds 461, Nr. 37638/54, fol. 9860-71: Vernehmung O. Kaduk, 1 September 1961; Broad (1981: 153-5, 178-9).
} 
of them reported a sharpening of senses during their imprisonment. ${ }^{74}$ The senses also shaped their inner lives, setting off streams of sudden, unbidden memories. ${ }^{75}$ The rare taste of home-baked bread was a reminder of freedom, as was the unfamiliar feeling of sitting on a proper chair. The sight of a distant fire evoked memories of roaring fireplaces back home, and the murmur of a quiet prayer transported prisoners back to the synagogues and churches of their childhood. When Primo Levi, who had studied chemistry in Turin, entered an IG Farben lab, he was hit by fumes from the past: 'For a moment the large semidark room at the university, my fourth year, the mild air of May in Italy comes back to me with brutal violence and immediately vanishes. ${ }^{976}$

Despite the critical significance of the senses for prisoners, they are mostly absent from academic studies of Auschwitz. Back in the 1970s, the pioneering Holocaust scholar Terrence Des Pres pointed out that we 'tend to forget how camp prisoners looked and smelled'. But few historians have followed his lead to examine the more visceral elements of camp life, and how they related to lived experience- - held back, perhaps, by fears that it might sully the victims' dignity. ${ }^{77}$ But blocking out the bodily reality of SS neglect and abuse only helps to sanitise the camps and sanctify the victims, creating yet more myths, reinforced by visits to memorials that give the 'impression of being almost clinically clean'. ${ }^{78}$

To imagine Auschwitz, one has to imagine a daily assault on all the senses, from the stench, which still haunted survivors decades later, to the soundscape of SS power. Inmates were stripped of all personal belongings on arrival, and in the absence of clocks and watches, it was the camp's gongs, bells, sirens and whistles that dictated the daily rhythm, marking prisoner time and ruling prisoner movements, starting with reveille and roll call in the morning. Although prisoner perceptions of temporality sometimes faded, as one day dissolved into the next- 'dates were not important then', one survivor recalled - each single day was segmented by SS sounds. Anyone who missed a beat was in grave danger. Inmates who could not hear or see were doomed, as were some who became indifferent to their own foul odour. ${ }^{79}$ Illness, violence and

\footnotetext{
${ }^{74}$ On heightened senses: see, for example, Pilecki (2012: 58).

${ }^{75}$ On the relationship between sensory perception and memory: Hamilakis (2015: 117-18); Stewart (2005).

${ }^{76}$ Levi (1987: 145). See also: Gradowski (2017: 105); Millu (1999: 19); Sobolewicz (1993: 174-5); Strzelecka (2002: 231).

${ }^{77}$ Des Pres (1980: 60). Exceptions include Classen et al. (1994: 172-5); Gigliotti (2010, 156-61); Rindisbacher (2006).

${ }^{78}$ Theune (2010: 10). See also Tietjen (2016: 4).

${ }^{79}$ Quote in Gutheil et al. (1984: 82). See also: Cegłowska (185: 183); Hamburger Institut (1994: II, 35-6); Herrmann (1994: 31); Piętka (2012: 194); Ryn \& Kłodziński (1994); Strzelecka (2002: 185). For pioneering aural studies of Nazi terror and the Holocaust: Košir (2017); Gerlach (2018). For time in Nazi camps and the Holocaust more generally: Sofsky (1997: 88-97); Goldberg (2010: 402-3). For background: Schafer (1994:161-8).
} 
deprivation affected prisoner senses in many ways, from a loss of balance to hunger hallucinations playing tricks on their vision, turning a piece of wood into a bread crust, bricks into loaves, tree roots into sausages. ${ }^{80} \mathrm{~A}$ history of the senses in Auschwitz needs to expand on these different aspects, as well as on their interrelation.

How such an approach might add to our sense of Auschwitz can be shown by a brief study of its space-specific 'smellscape', building on De Pres' insights. ${ }^{81}$ In his work, Des Pres focused on the 'excremental assault' of camps like Auschwitz. Prisoners and their compounds were steeped in urine and faeces. Skin and clothes were encrusted, as were bunks and floors. Latrines, often no more than a plank over a putrid ditch, gave off a nauseating smell, which merged with that of rotting and burning bodies. ${ }^{82}$ Des Pres was wrong to interpret this stench as a deliberate SS strategy to debase prisoners and destroy their spirit; it was rather a consequence of starvation rations and overcrowding. ${ }^{83}$ But he was right to explore olfactory aspects of a place like Auschwitz. Excrement was all around, after all, because sanitary conditions were so poor and so many prisoners suffered from diarrhoea; some had to empty their bowels over twenty times a day. Diarrhoea shamed and gravely weakened inmates, and their desperate battle against it was 'one of Auschwitz's unwritten stories', according to the Polish survivor Tadeusz Borowski. ${ }^{84}$

The stench enveloped entire compounds, drifting across boundaries. 'In the early days of the Birkenau camp', one former inmate recalled, 'the distinctive stink could be smelled within a radius of at least one kilometre. ${ }^{95}$ Still, there was no single, uniform scent and not all prisoners smelled alike, either. In the same way as class distinctions on the outside had an olfactory dimension, smell inside the camp became a marker of prisoner hierarchies, and further magnified them. ${ }^{86}$ The few privileged prisoners had access to sufficient water, scented soap, medication and clean clothes, sometimes even perfume, which they 'organised' from magazines holding the property of murdered Jews; others smelled of secretly procured cigarettes and alcohol. ${ }^{87}$ The lowermost prisoners, meanwhile, ill and apathetic, gave off the most pungent odour, and were often shunned and ostracised by fellow inmates, both socially and spatially; it was not unusual for sick prisoners, who had soiled themselves, to be beaten and dragged out

\footnotetext{
${ }^{80}$ Hamburger Institut (1994: I, 112, 145; II, 126-8); Langbein (1995: 146). More generally: Cornish et al. (2017: 2-3).

${ }^{81}$ For the term: Porteous (2006).

${ }^{82}$ Des Pres (1980: 51-71).

${ }^{83}$ Des Pres (1980: 57-60). For the consequences of hunger and overcrowding: Dwork \& van Pelt (1997: 268); Fejkiel (1964).

${ }^{84}$ Tietjen (2016: 8-13, quote on 12). See also Levi (2006: 48-51).

${ }^{85}$ Hamburger Institut (1994: II, 167).

${ }^{86}$ See, for example, Alain Corbin's work on the 'stench of the poor': Corbin (1986: 142-60).

${ }^{87}$ Shelley (1996: 72); Strzelecka (2012: 91, footnote 76).
} 
of dormitories by other inmates. ${ }^{88}$ Social standing shaped other sensory experiences as well, including touch, with privileged prisoners wearing comfortable leather shoes, while many others marched in heavy wooden clogs, causing abrasions, blisters and infections, that could set them on the road to death. ${ }^{89}$

With smell being culturally mediated, like the other senses, prisoner experiences were affected by pre-existing cultural values. The revulsion of male prisoners at the stench of women in Birkenau, for example, reflected their shock at the breach of traditional, gendered norms, which associated 'respectable' women with fragrant, sweet or homely scents. ${ }^{90}$ Similarly, a particular smell regarded as pleasant by one group could be disgusting to another, depending on their national or local traditions. ${ }^{91}$

But Auschwitz also altered sensibilities. Not only would prisoners force down stinking food by holding their noses, they often became more tolerant of 'bad' smells, or stopped registering them altogether: 'our nostrils were besmirched with our own stink and could no longer smell anything', Charlotte Delbo recalled. ${ }^{92}$ This process of adaption and habituation can be illustrated by returning to the Auschwitz latrine. In Des Pres' reading, it signified nothing but humiliation, torture and death ${ }^{93}$ But its true meaning was more complex. For all the suffering that took place here, some inmates associated the smell of the latrines with safety. The Kapos (prisoners overseeing other prisoners) who supervised those emptying the ditches saw it as a cushy job, while the regular prisoners who worked here relished the extra food they received. Other inmates sometimes sought refuge in latrines - from the rain and the guards, who were repelled by the smell - and briefly rested here, talked or traded with comrades. Some even ate inside the latrines, unperturbed by the stench, the sound of defecating prisoners and the sight of their festering buttocks. For Primo Levi, the latrine was 'an oasis of peace'. ${ }^{94}$

It was a different matter for the perpetrators, who were keen to distance themselves from the stench of Auschwitz by preserving a more deodorised environment, free from natural bodily odours and excretions. When guards returned from a day inside the camp, they could change their clothes and wash the smell of death and decay off their

\footnotetext{
${ }^{88}$ For some examples: Fejkiel (1964: 7); Sobolewicz (1993: 78-9).

${ }^{89}$ Benninga (2018: 199). See also Theune (2018: 505-7). On the materiality of Nazi terror more generally: Bernbeck (2017).

${ }^{90}$ Classen et al. (1994: 3, 83, 162); Hamburger Institut (1994: I, 136); Kret (1959: 111).

${ }^{91}$ See, for example, the prisoner practice of eating frogs' legs: Hamburger Institut (1994: I, 248). More generally, Fitzgerald \& Petrick (2008).

${ }^{92}$ Delbo (1995: 150). See also Hamburger Institut (1994: I, 32).

${ }^{93}$ Des Pres (1980: 58-9).

${ }^{94}$ Levi (1987: 74). See also: Adelsberger (2005: 91-2); Leo Baeck Institute, ME 645, A. Trautmann, '62118 in Auschwitz', pp 13-14; Millu (1999: 116); Strzelecka (2002: 222); Zywulska (2011: 37).
} 
bodies, in bathrooms or staff saunas built for cleansing and relaxation. ${ }^{95}$ At the same time, they regarded the sickening odour of the camp as further proof that the prisoners - depicted as dangerous, dirty and diseased deviants by SS propaganda-were subhuman and deserved what was coming to them. The smell of excrement had long been associated with beasts, after all, while other 'bad smells' were popularly regarded as signs of illness and corruption. Dominant social groups often attribute such 'bad smells' to the 'other' - the poor, prostitutes, criminals, ethnic minorities - and this practice was heightened in Auschwitz, above all in the case of Jews. ${ }^{96}$

The supposed malodour of Jews was a long-standing anti-Semitic trope- 'I often grew sick to my stomach from the smell of these caftan-wearers', Adolf Hitler wrote in Mein Kampf - that was reinforced in Auschwitz by the catastrophic conditions created by the SS and its accomplices: he had allowed Polish prisoners to wash in one of the ponds, a German Kapo later testified, but 'naturally not the Jews'. It was not just SS staff and Kapos who subscribed to the 'racist politics of smell'. When Primo Levi once dared to address one of the civilian laboratory workers at IG Farben, she immediately complained to her supervisor about the affront of this 'stinking Jew'. ${ }^{97}$

Some exceptions were made by SS staff, driven by their own self-interest. For instance, selected Jewish prisoners working in SS offices, such as the Political Department, were moved from the abysmal barracks in Birkenau to a well-appointed building near the main camp, complete with hot showers, laundry and flushing toilets, where they could wash frequently and received better uniforms and food. All this was meant to spare SS managers the most offensive sights and smells, and to protect them from illness. But not all were reassured. Unterscharführer Bernhard Kristan from the Political Department, for one, was petrified to touch the door handle to an office of Jewish prisoner clerks, opening it instead with his elbow. ${ }^{98}$ Evidently, fears ran deep among the SS, not just the prisoners, pointing to the camp's complex emotional landscape.

\footnotetext{
${ }^{95}$ Classen et al. (1994: 175); Jaskot et al. (2014: 171-2); Kreutz \& Strobel (2018: 169). More generally: Jenner (2011).

${ }^{96}$ Classen et al. (1994: 173); Corbin (1986: 227); Dendooven (2017: 183); Des Pres (1980: 61); Jenner (2011: 346); Lang (2010: 227); Smith (2007: 65-74).

${ }^{97}$ Quotes (in order) in: Classen et al. (1994: 173); Bundesarchiv Ludwigsburg, B 162/14.351, Landgericht Frankfurt, Strafsache gegen B. Bonitz, J. Windeck, 14 June 1968, here p. 97; Classen et al. (1994: 173); Levi (1987: 149).

${ }^{98}$ Adler et al. (1994: 148); Shelley (1992); Spritzer (1994).
} 


\section{Emotional spaces}

When it comes to the systematic study of emotions, another core element of lived experience, much of the history of the Holocaust remains a blank slate. In the case of Auschwitz, such a study could begin by probing 'collective emotional standards'. 99 The SS, for example, can be seen as an 'emotional community', which distinguished desirable feelings from deviant ones, and prescribed specific ways for their expression. ${ }^{100}$ For example, SS men were expected to demonstrate warmth towards their families and their comrades. Family life was idealised as a sanctuary: 'When you and the little ones were with me in Au[schwitz]', chief garrison physician Dr Eduard Wirths wrote to his wife in December 1944, 'one could feel nothing of the war!' Likewise, SS men were supposed to bask in the glow of 'heart-warming comradeship', as one Camp SS leader put, though such appeals were often overshadowed by the daily reality of petty jealousies and personal animosity. ${ }^{101}$

In front of the prisoners, SS staff were meant to keep up their guard. Above all else, they were not to show empathy for suffering inmates. Occasional disquiet about the fate of a particular victim, such as a crying child, may be tolerated in private. But open displays of discomfort or dismay about the atrocities were strictly off-limits, as in the case of SS physician Dr Hans Delmotte, who suffered a mental collapse after witnessing his first selection of Jews for the gas chambers. One of his colleagues recalled that Dr Delmotte was 'completely destroyed' afterwards. 'Never again since have I seen as severe a nervous break-down as he suffered.' ${ }^{102}$

Dr Delmotte's behaviour amounted to a flagrant breach of 'display rules', which demanded that SS staff act impassively in the face of mass murder. ${ }^{103}$ How this should be done was demonstrated from on high by Auschwitz Commandant Rudolf Höss, who describes in his memoirs (written shortly before his execution in April 1947) how he repressed feelings of distress: since his subordinates watched him closely for social cues during the selections, he had to appear cold and heartless, even when screaming children were forced into the gas chambers and 'all-too-human emotions rose up' inside him: 'I could not show the slightest sympathy.'104 The emotional ideal Höss modelled for his men was that of the 'political soldier', who was in complete control of his feelings: he acted in cold blood, with a stony heart and iron fist, without, however, taking pleasure in the victims' pain. Höss clung to a perverted ideal of decency,

\footnotetext{
${ }^{99}$ Stearns \& Stearns (1985: 813).

${ }^{100}$ Rosenwein (2002: 842).

${ }^{101}$ Wachsmann (2015: 102, 374).

${ }^{102}$ Quote in Shelley (1991: 292). See also Langbein (1995: 530).

${ }^{103}$ The term 'display rules' is quoted in Scheer (2012: 215).

${ }^{104}$ Нӧß (1994: 198).
} 
emulating SS leader Heinrich Himmler, who wanted his men to feel proud about writing 'a glorious page in our history' (as he called the Holocaust), but also imagined them acting 'hard, without being cruel'. Many SS men on the ground made no such distinction and committed furious assaults. Some carried out theatrical displays of hatred to advance their careers, others were moved by boredom, rage, fear and disgust. Specific spaces, like the roll-call square, soon became associated with the performance of extreme public violence. ${ }^{105}$

SS violence established clear-cut emotional norms for prisoner encounters with SS staff. Inmates soon learned that anyone who stood out could become a target. This made all open expressions of emotion potentially dangerous, since any sound or gesture - of anger, pain, distress - could attract attention. Whatever the circumstances, inmates strained to be impassive and inconspicuous, trying hard not to be heard or seen by the SS. They had to 'curl up inside' and diminish their 'presence to zero', recalled the survivor Sigmund Sobolewski. 'You had thick walls; your face revealed nothing. ${ }^{106}$

These emotional restrictions extended throughout the camp's public routines and spaces. One day in 1942, a Jewish prisoner clerk, who had to process the camps' records of individual prisoner deaths, came across the notice of her own brother's death. She slumped forward and began to sob into her hands. After she heard SS voices next door, she desperately calmed herself. 'She stopped crying', one of her friends recalled. 'Only her red eyes and the shivers running through her body attested to how much she suffered.' 107

Other inmates could not cry at all, it seems, deadened by the horror of the camp and the unrelenting struggle to survive. He was unable to 'breathe a sigh or shed a tear' for his murdered family, Zalmen Gradowski wrote in spring 1944. 'In the nearly 16 months I have spent in this life of hell, I have not yet had a single day to withdraw into my own world, to sense, perceive, feel my great misfortune.' This suggests a numbing of emotions, and yet Gradowski's secret notes are suffused with feeling, including his burning desire for revenge: 'may those who turned my people into a sea of blood themselves drown in seas of blood'. ${ }^{108}$

${ }^{105}$ Himmler quotes in Institut für Zeitgeschichte (Munich), MA 312, Rede bei der SS Gruppenführerbesprechung, 8 November 1938; Rede bei der SS Gruppenführertagung in Posen, 4 October 1943, reprinted in Trial (1948: 145). See also: Biess (2010: 31-2); Dillon (2015); Mailänder (2015); Wachsmann (2015: 100-18, 365-71). On SS pride: Lang (2018). On the performance of emotions: Rosenwein (2002: 841).

${ }^{106}$ Quotes in Tanenbaum (1998: 131, 149). See also Gerlach (2018: 12), here in relation to Jews during the Holocaust more generally.

${ }^{107}$ Adler et al. (1994: 151). For another example: Lill (1978: 153). More generally on the importance of avoiding deviant emotions under strict emotional regimes: Reddy (2001: 124-5).

${ }^{108}$ Quotes in Gradowski (2017: 78, 77). On feelings of numbness among Auschwitz prisoners: Kraft (2004: 357-8). 
Clearly, SS domination did not rob prisoners of all feeling. It did not turn them into 'ghastly marionettes with human faces', as Hannah Arendt, the philosopher of totalitarianism, once claimed. ${ }^{109}$ Prisoners put up a front in SS-patrolled areas, but they expressed themselves differently elsewhere. Spaces outside the immediate supervision of the SS-like the latrine or prisoner barracks at night - could function as 'emotional refuges', where inmates contravened the emotional standards imposed by the SS. ${ }^{110}$

Survivor memoirs attest to a highly complex emotional life in Auschwitz, full of anguish and envy, pity, friendship and love. Further research will reveal more about the significance of these emotions, their construction, and their communication in a multinational social space where most inmates did not share a language. ${ }^{111}$ Survivor testimonies suggest, for instance, that many prisoners felt deep shame on arrival, when they had to undress for the first time for the showers and the shaving of their body hair. But how were these feelings gendered? How were they affected by long-standing cultural and religious traditions? And, from a methodological perspective, how much can memoirs and oral testimonies, produced years or decades after the event, tell us about this experience of shame? Should we focus less on post facto descriptions of inner states, and more on observable practices and actions, such as prisoners turning away and covering themselves, or breaking into wild laughter at the grotesque sight of naked bodies shorn of all individuality? ${ }^{112}$

\section{Conclusion}

In his desperate plea, written in the face of almost certain death, Zalmen Gradowski asks us to do the impossible: to imagine all the horror of Auschwitz. In its totality, Auschwitz lies beyond our imagination. Still we must try. Otherwise the resulting void will continue to be filled by myths. ${ }^{113}$ To paraphrase Tony Judt: because the Holocaust cannot be remembered exactly as it was, it is liable to be remembered as it was not. ${ }^{114}$

\footnotetext{
${ }^{109}$ Arendt (1976: 455).

${ }^{110}$ For the concept of 'emotional refuge': Reddy (2001: 128-9).

${ }^{111}$ For multilingual life in the camps: Wolf (2016).

${ }^{112}$ For survivor accounts of shame: Amesberger et al. (2004: 70-9); Graf (2015: 43-71); Pozner (1985: 33-4). On the gendering of emotions more generally: Bourke (2014: 192-214). On emotions as an observable practice: Scheer (2012).

${ }^{113}$ On this paradox, see also Didi-Huberman (2007a: 15). Still insightful on the relationship between historical construction and imagination: Collingwood (2005: 231-49).

${ }^{114}$ Judt (2007: 830).
} 
The task of historians, Primo Levi wrote, is to combat 'simplification and stereotype' by helping others to better 'perceive the experience' of the camps. ${ }^{115}$ This might be achieved, this paper has proposed, by paying closer attention to the spatial, sensory and emotional aspects of Auschwitz, and their intersection. ${ }^{116}$ Exploring the material worlds of bodies and spaces, and their subjective dimension, brings us closer to the multifaceted experience of the historical actors, making the camp less of a mythical abstraction. But this is more than a descriptive exercise. This approach not only renders Auschwitz more recognisable, it also points to new analytical perspectives and adds to historiographical debates about Nazi terror, such as the nature of SS might and its limits; the forces driving SS policy and violence (measuring long-term ideological designs against short-term structural pressures); the scope and significance of prisoner agency; the stratification of prisoner society along racial and gender lines; the power of the camps to upend established norms; and the relationship between sites of repression and the wider world outside. ${ }^{117}$

Seen through the compound lens of lived experience, even the smallest spaces can reveal a lot about Auschwitz. Consider the bunk, which loomed large in prisoner lives, but has attracted little scholarly interest. ${ }^{118}$ Inmates who made it back to their sleeping quarters, after another seemingly endless day of suffering, knew that for the next few hours, at least, the SS would likely leave them in peace. Few, however, could find any real rest. Pressed into suffocatingly small spaces, many prisoners dreaded the night. The wooden shavings and rotting straw, used as bedding on three-tiered bunks, crawled with fleas and chaffed against sore skins. Obscured by the darkness and the maze of bed frames, prisoners often could not see who lay near them. But they smelt their neighbours and felt their bony elbows and knees, sparking angry clashes. When a prisoner moved or got up to defecate in one of the buckets, others had to move too, causing more rows. All the scuffles kept prisoners awake, as did the stench from the buckets, above all in the heat of summer. Others were jolted awake by sudden groans from the sick and those in the grip of nightmares, or by screams and slaps of Kapos trying to restore order. In short, the agony of Auschwitz was not suspended at night. Looking at the emotions and sensations attached to the bunks reminds us that this

\footnotetext{
${ }^{115}$ Levi (1989: 128).

${ }^{116}$ So far, this intersection has only rarely been explored in histories of Auschwitz. One exception is the so-called ramp, where deportation trains arrived: see Cole (2016: 109-12); Gigliotti (2010: 179-98); Wachsmann (2016: 307-12). Historians of Auschwitz could take a cue from pioneering scholarship in other fields: Davidson \& Milligan (2004); Hemer \& Dundon (2016). See also the journal Emotion, Space and Society.

${ }^{117}$ For background on these historiographical debates: Wachsmann (2016).

${ }^{118}$ Exceptions include Cole (2016: 71, 86-91). For a brief analysis, examining Nazi camps more generally: Sofsky (1997: 85-7).
} 
agony was unceasing, that it weakened prisoners and exacerbated tensions between them, making solidarity and friendship all the harder. ${ }^{119}$

At the same time, we must not simplify prisoner experiences. Not every place was the same. Some inmates shared their bunk with close comrades and made it their temporary home. Conditions also varied by location. Generally, bunks in the main camp were preferable to the ones in muddy Birkenau, often smeared with dirt. As for the tiers, most prisoners preferred the top. It might be colder and damper up there, especially when the roof leaked, but at least they could sit up and stretch. What is more, they were protected from the trickle of straw dust and excrement that fell onto lower bunks, and also from the soiled feet of inmates who stepped onto heads and arms as they clambered down to relieve themselves. Prisoners learned about these differences from experience, as they rarely remained in the same bunk for long. Changes in SS zoning, new labour assignments or illness could lead to an abrupt change in quarters, adding to the perpetual flux of Auschwitz. Often, it was prisoners themselves who took the initiative, using cunning and connections to improve their lot. The higher up the hierarchy, the greater their influence over the spaces they occupied. Some eventually slept alone in more comfortable surroundings, away from the mass of inmates, and held onto their beds as places of refuge. ${ }^{120}$

Zalmen Gradowski was among these more privileged prisoners, because the Sonderkommando occupied better quarters. In his secret notes, composed in the months before his murder, he often mentions the bunk, picturing it as a deeply ambivalent place. It was a site of great misery, where Sonderkommando prisoners were tormented by memories of the deceased. Wherever they looked, they could see traces of comrades, now dead, who once shared the bunks. And when they closed their eyes, they often relived the agony - the sights, sounds, smells - they had witnessed that day at the gas chambers. And yet, the bunk could also exude comfort, as the misery of the Sonderkommando was sometimes forgotten amid friendship and laughter, study and worship. It was also a place where pain could dissolve into brief, blissful dreams, filled with sweet sensations. But such dreams made waking up all the more terrifying. Half asleep, Gradowski writes, a prisoner would still see the faces of loved ones, hear their laughter and feel their warm touch. But then he realised, with bottomless dread, where he was and that his family was long gone. 'Lonely, forlorn, solitary, broken. Ah, why,

\footnotetext{
${ }^{119}$ Batthyany et al. (2005: 64); Bezwińska \& Czech (1996: 164); Iwaszko (2000: 53-5); Jagoda et al. (1994: 192-4); Levi (1987: 63-9); Millu (1999: 150-1); Pozner (1985: 38-9); Ryn \& Kłodziński (1994: 113); Siedlecki et al. (2000: 22-5).

${ }^{120}$ Adler et al. (1994: 28-9); Greif (1995: 81, 174); Pawełczyńska (2001: 64-6); Siedlecki et al. (2000: 23); Strzelecka (2009: 38); Szmaglewska (2008: 16); Venezia (2009: 46-7).
} 
for what purpose had the gong woken him? If only he could remain in this idyllic dream forever - asleep. He would die a happy death.' ${ }^{121}$

\section{Acknowledgements}

This article draws on my 2018 Elie Kedourie Memorial Lecture. I am very grateful to the British Academy for the opportunity to give this lecture, and for the Holocaust Educational Foundation for inviting me to give a related lecture at Northwestern University in 2019. For their comments on this article, I am greatly indebted to Tal Bruttmann, Jane Caplan, Matthew Champion, Tim Cole, Chris Dillon, David Feldman, Christoph Kreutzmüller, Peter Singer and Kim Wünschmann. Extracts of the article were published in Wachsmann (2020), around the time of the 75 th anniversary of the liberation of Auschwitz.

\section{References}

Adelsberger, L. (2005), Auschwitz. Ein Tatsachenbericht (Bonn, Bouvier).

Adler, H.G., Langbein, H. \& Lingens-Reiner, E. (eds) (1994), Auschwitz. Zeugnisse und Berichte (Hamburg, Europäische Verlagsanstalt).

Aly, G. (2007), Hitler's Beneficiaries (New York, Metropolitan).

Aly, G. \& Gerlach, C. (2002), Das letzte Kapitel (Stuttgart, DVA).

Aly, G. \& Heim, S. (1993), Vordenker der Vernichtung (Frankfurt a. M., Fischer).

Amesberger, H., Auer, K. \& Halbmayr, B. (2004), Sexualisierte Gewalt (Wien, Mandelbaum).

Arendt, H. (1976), The Origins of Totalitarianism (San Diego, CA, Harcourt).

Bartov, O. (2000), Mirrors of Destruction (Oxford, Oxford University Press).

Batthyany, A., Biller, K. \& Fizzotti, E. (eds) (2005), Viktor E. Frankl. Gesammelte Werke, vol. 1 (Wien, Böhlau).

Benninga, N. (2018), 'The Bricolage of Death. Jewish Possessions and the Fashioning of the Prisoner Elite in Auschwitz-Birkenau, 1942-1945', in L. Auslander \& T. Zahra (eds), Objects of War (Ithaca, NY, Cornell University Press), 189-220. https://doi.org/10.7591/9781501720086-012

Bernbeck, R. (2017), Materielle Spuren des nationalsozialistischen Terrors (Bielefeld, Transcript). https://doi.org/10.14361/9783839439678

Bernstein, M. (2016), '3-D-Modell von Auschwitz soll NS-Verbrecher überführen', Süddeutsche Zeitung, 29 August 2016.

Bezwińska, J. \& Czech, D. (eds) (1981), KL Auschwitz in den Augen der SS (Katowice, Krajowa Agencja Wydawnicza).

Bezwińska, J. \& Czech, D. (eds) (1996), Inmitten des grauenvollen Verbrechens (Oświęcim, Verlag Staatliches Auschwitz-Birkenau Museum).

Biess, F. (2010), 'Feelings in the Aftermath: Toward a History of Postwar Emotions', in F. Biess \& R.G. Moeller (eds), Histories of the Aftermath (New York, Berghahn), 30-48.

Bornstein, E. (2015), The Long Night (London, Toby Press).

${ }^{121}$ Gradowski (2017: 90-8, quote on 95). See also Piper (2000: 189-97). On the terror of waking up in Auschwitz, see also: Des Pres (1980: 75); Jagoda et al. (1994: 194-5). 
Bourdieu, P. (1989), 'Social Space and Symbolic Power', Sociological Theory, 7: 14-25. https://doi.org/10.2307/202060

Bourke, J. (2014), The Story of Pain (Oxford, Oxford University Press).

Broad, P. (1981), 'Erinnerungen', in J. Bezwińska \& D. Czech (eds), KL Auschwitz in den Augen der SS (Katowice, Krajowa Agencja Wydawnicza), 133-95.

Browning, C. (1996), Ganz normale Männer (Reinbek, Rowohlt).

Browning, C. (2004), The Origins of the Final Solution (London, William Heinemann).

Brudholm, T. \& Lang, J. (eds) (2018), Emotions and Mass Atrocity (Cambridge, Cambridge University Press). https://doi.org/10.1017/9781316563281

Bruner, E.M. (1986), 'Experience and its Expressions', in V.W. Turner \& E.M. Bruner (eds), The Anthropology of Experience (Urbana, IL, University of Illinois Press), 3-32.

Bull, M., Gilroy, P., Howes, D. \& Kahn, D. (2006), 'Introducing Sensory Studies', The Senses and Society, 1: 5-7. https://doi.org/10.2752/174589206778055655

Busch, C., Hördler, S. \& van Pelt, R.J. (eds) (2016), Das Höcker Album (Darmstadt, WBG).

Carr, G., Jasinski, M. \& Theune, C. (2018), 'The Material Culture of Nazi Camps', International Journal of Historical Archaeology, 22: 423-9. https://doi.org/10.1007/s10761-017-0444-z

Cegłowska, T. (1985), 'Strafkompanien im KL Auschwitz', Hefte von Auschwitz, 17: 157-204.

Chare, N. \& Williams, D. (2017), Matters of Testimony (New York, Berghahn).

Charlesworth, A. (2004), 'The Topography of Genocide', in D. Stone (ed.), The Historiography of the Holocaust (Houndmills, Palgrave Macmillan), 216-52. https://doi.org/10.1057/9780230524507_11

Ciechanower, M. (2015), A Star Gleams in the Distance (USA, Daniel Schlessinger).

Citroen, H. \& Starzyńska, B. (2011), Auschwitz-Oświęcim (Rotterdam, Post Editions).

Classen, C. (1993), Worlds of Sense: Exploring the Senses in History and Across Cultures (London, Routledge).

Classen, C. (2012), The Deepest Sense: A Cultural History of Touch (Urbana, IL, University of Illinois Press). https://doi.org/10.5406/illinois/9780252034930.001.0001

Classen, C., Howes, D. \& Synnott, A. (1994), Aroma. The Cultural History of Smell (London, Routledge).

Cole, T. (2003), Holocaust City: The Making of a Jewish Ghetto (New York, Routledge).

Cole, T. (2016), Holocaust Landscapes (London, Bloomsbury).

Collingwood, R.G. (2005), The Idea of History, 2nd edn (Oxford, Oxford University Press).

Confino, A. (2014), A World Without Jews (New Haven, CT, Yale University Press).

Corbin, A. (1986), The Foul and the Fragrant (Leamington Spa, Berg).

Cornish, P., Saunders, N. \& Smith, M. (2017), 'Introduction', in N. Saunders \& P. Cornish (eds), Modern Conflict and the Senses (London, Routledge), 1-9. https://doi.org/10.4324/9781315682228-1

Cresswell, T. (2006), On the Move (London, Routledge).

Czech, D. (1989), Kalendarium der Ereignisse im Konzentrationslager Auschwitz-Birkenau 1939-1945 (Reinbek, Rowohlt).

Davidson, J. \& Milligan, C. (2004), 'Embodying Emotion Sensing Space: Introducing Emotional Geographies', Social and Cultural Geography, 5: 523-32. https://doi.org/10.1080/1464936042000317677

De Certeau, M. (1988), The Practice of Everyday Life (Berkeley, CA, University of California Press).

Delbo, C. (1995), Auschwitz and After (New Haven, CT, Yale University Press).

Dendooven, D. (2017), 'Trench Crap: Excremental Aspects of the First World War', in N. Saunders \& P. Cornish (eds), Modern Conflict and the Senses (London, Routledge), 183-95. https://doi.org/10.4324/9781315682228-13

Des Pres, T. (1980), The Survivor (Oxford, Oxford University Press).

Didi-Huberman, G. (2007a), Bilder trotz allem (München, Wilhelm Fink). https://doi.org/10.30965/9783846740200 
Didi-Huberman, G. (2007b), 'The Site, Despite Everything', in S. Liebman (ed.), Claude Lanzmann's Shoah (Oxford, Oxford University Press), 113-23.

Dillon, C. (2015), Dachau and the SS (Oxford, Oxford University Press).

https://doi.org/10.1093/acprof:oso/9780199656523.001.0001

Długoborski, W. \& Piper, F. (eds) (2000), Auschwitz. 1940-1945, 5 vols (Oświęcim, Auschwitz-Birkenau State Museum).

Dörner, B. (2007), Die Deutschen und der Holocaust (Berlin, Propyläen).

Dwork, D. \& van Pelt, R.J. (1997), Auschwitz: 1270 to the Present (New York, W.W. Norton).

Eitinger, L. (1985), Psychological and Medical Effects of Concentration Camps and Related Persecutions on Survivors of the Holocaust (Vancouver, University of British Columbia Press).

Fejkiel, W. (1964), 'Der Hunger in Auschwitz', Hefte von Auschwitz, 8: 3-14.

Fitzgerald, G.J. \& Petrick, G.M. (2008), 'In Good Taste: Rethinking American History with Our Palates', The Journal of American History, 95: 392-404. https://doi.org/10.2307/25095625

Forum (2010), 'History of Emotions', German History, 28: 67-80. https://doi.org/10.1093/gerhis/ghp108 Frankenthal, H. (2002), The Unwelcome One (Evanston, IL, Northwestern University Press).

Frei, N. Grotum, T., Institut für Zeitgeschichte, Parcer, J., Steinbacher, S. \& Wagner, B.C. (eds) (2000), Standort- und Kommandanturbefehle des Konzentrationslagers Auschwitz 1940-1945 (München, K.G. Saur). https://doi.org/10.1515/9783110958324

Frevert, U. (2009), 'Was haben Gefühle in der Geschichte zu suchen?', Geschichte und Gesellschaft, 35: 183-208. https://doi.org/10.13109/gege.2009.35.2.183

Friedländer, S. (2007), 'Die "Endlösung". Über das Unbehagen in der Geschichtsdeutung', in S. Friedländer, Nachdenken über den Holocaust (München, C.H. Beck), 125-39.

Friedländer, S. (2009), Nazi Germany and the Jews, 1933-1945 (New York, Harper).

Fröbe, R. (2000), 'Bauen und Vernichten. Die Zentralbauleitung Auschwitz und die "Endlösung"', Beiträge zur Geschichte des Nationalsozialismus, 16: 155-209.

Gammerl B. \& Herrn, R. (2015), 'Gefühlsräume-Raumgefühle. Perspektiven auf die Verschränkung von emotionalen Praktiken und Topografien der Moderne', sublurban. Zeitschrift für kritische Stadtforschung, 3(2): 7-22. https://doi.org/10.36900/suburban.v3i2.190

Geertz, C. (1986), 'Making Experience, Authoring Selves', in V.W. Turner \& E.M. Bruner (eds), The Anthropology of Experience (Urbana, IL, University of Illinois Press), 373-80.

Gerlach, C. (2018). 'Echoes of Persecution: Sounds in Early Post-liberation Jewish Memories', Holocaust Studies, 24: 1-25. https://doi.org/10.1080/17504902.2017.1319247

Giaccaria, P. \& Minca, C. (2011), 'Topographies/Topologies of the Camp: Auschwitz as a Spatial Threshold', Political Geography, 30: 3-12. https://doi.org/10.1016/j.polgeo.2010.12.001

Giaccaria, P. \& Minca, C. (eds) (2016a), Hitler's Geographies (Chicago, IL, University of Chicago Press). https://doi.org/10.7208/chicago/9780226274560.001.0001

Giaccaria, P. \& Minca, C. (2016b), 'For a Tentative Spatial Theory of the Third Reich', in P. Giaccaria \& C. Minca, C. (eds), Hitler's Geographies (Chicago, IL, University of Chicago Press), 19-44. https://doi.org/10.7208/chicago/9780226274560.001.0001

Gigliotti, S. (2010), The Train Journey (New York, Berghahn). https://doi.org/10.2307/j.ctt9qd53n

Goldberg, A. (2010), 'Jews's Diaries and Chronicles', in P. Hayes \& J.K. Roth (eds), The Oxford Handbook of Holocaust Studies (Oxford, Oxford University Press), 397-413. https://doi.org/10.1093/oxfordhb/9780199211869.003.0027

Goldberg, A. (2017), Trauma in First Person. Diary Writing During the Holocaust (Bloomington, IN, Indiana University Press). https://doi.org/10.2307/j.ctt1zxz15p

Goldhagen, D.J. (1996), Hitler's Willing Executioners (London, Abacus).

Gradowski, Z. (2017), From the Heart of Hell (Oświęcim, Auschwitz-Birkenau State Museum).

Graf, M. (2015), Erinnerung erschreiben: Gender-Differenz in Texten von Auschwitz-Überlebenden (Frankfurt a. M., Campus). 
Greif, G. (1995), Wir weinten tränenlos...Augenzeugenberichte der jüdischen 'Sonderkommandos' in Auschwitz (Köln, Böhlau). https://doi.org/10.7788/boehlau.9783412309244

Greif, G. \& Siebers, P. (2016), Todesfabrik Auschwitz (Köln, emons).

Gross, R. \& Renz, W. (eds) (2013), Der Frankfurter Auschwitz-Prozess (1963-1965). Kommentierte Quellenedition, vol. 2 (Frankfurt a. M., Campus Verlag).

Gutheil, J.-E. et al. (eds) (1984), Einer muß überleben: Gespräche mit Auschwitzhäftlingen 40 Jahre danach (Düsseldorf, dkv).

Gutman, Y. \& Berenbaum, M. (eds) (1998), Anatomy of the Auschwitz Death Camp (Bloomington, IN, Indiana University Press).

Gutschow, N. (2001), Ordnungswahn: Architekten planen im 'eingedeutschten Osten' 1939-1945 (Basel, Birkhäuser). https://doi.org/10.1515/9783035602548

Hamburger Institut für Sozialforschung (ed.) (1994), Die Auschwitz-Hefte, 2 vols. (Hamburg, Roger \& Bernhard).

Hamilakis Y. (2015), Archaeology and the Senses (Cambridge, Cambridge University Press).

Hayes, P. (2017), Why? Explaining the Holocaust (New York, W.W. Norton).

Hemer, S. \& Dundon, A. (eds) (2016), Emotions, Senses, Spaces: Ethnographic Engagements and Intersections (Adelaide, University of Adelaide Press). https://doi.org/10.20851/emotions

Herrmann, H.J. (1994), 'Mein Kampf' gegen die Endlösung (Wien, Löcker Verlag).

Hördler, S. (2015), Ordnung und Inferno: Das KZ-System im letzten Kriegsjahr (Göttingen, Wallstein).

Höß, R. (1994), Kommandant in Auschwitz (München, dtv).

Howes, D. (2008), 'Can These Dry Bones Live? An Anthropological Approach to the History of the Senses', The Journal of American History, 95: 442-51. https://doi.org/10.2307/25095629

Iwaszko, T. (2000), 'The Housing, Clothing and Feeding of the Prisoners', in W. Długoborski \& F. Piper (eds), Auschwitz. 1940-1945 (Oświęcim, Auschwitz-Birkenau State Museum), vol. 2: 51-63.

Jagoda, Z., Kłodziński, S. \& Masłowski, J. (1994), “'Die Nächte gehören uns nicht”. Häftlingsträume in Auschwitz und im Leben danach', in Hamburger Institut für Sozialforschung (ed.), Die AuschwitzHefte (Hamburg, Roger \& Bernhard), vol. 2: 189-239.

Jaskot, P. (2017), 'Architecture of the Holocaust', Joseph and Rebecca Meyerhoff Annual Lecture 2016 (Washington, United States Holocaust Memorial Museum).

Jaskot, P., Knowles, A. \& Harvey, C. (2014), 'Visualizing the Archive: Building at Auschwitz as a Geographic Problem', in A.K. Knowles, T. Cole \& A. Giordano, A. (eds), Geographies of the Holocaust (Bloomington, IN, Indiana University Press), 158-91.

Jay, M. (1989), 'Songs of Experience: Reflections on the Debate over Alltagsgeschichte', Salmagundi, 81: $29-41$.

Jay, M. (2005), Songs of Experience: Modern American and European Variations on a Universal Theme (Berkeley, CA, University of California Press). https://doi.org/10.1525/9780520939790

Jenner, M. (2011), 'Follow Your Nose? Smell, Smelling, and Their Histories', The American Historical Review, 116: 335-51. https://doi.org/10.1086/ahr.116.2.335

Judt, T. (2007), Postwar: A History of Europe Since 1945 (London, Pimlico).

Jütte, R. (2005), A History of the Senses (Cambridge, Polity).

Kaienburg, H. (2003), Die Wirtschaft der SS (Berlin, Metropol).

Kalisky, A. (ed.) (2019), Salmen Gradowski. Die Zertrennung (Berlin, Suhrkamp).

Kershaw, I. (2002), Popular Opinion and Political Dissent in the Third Reich, 2nd edn (Oxford, Clarendon Press).

Kielar, W. (1979), Anus Mundi: Fünf Jahre Auschwitz (Frankfurt a. M., Fischer).

Klei, A., Stoll, K. \& Wienert, A. (2011), 'Einleitung', in A. Klei, K. Stoll \& A. Wienert (eds), Die Transformation der Lager (Bielefeld, Transcript), 9-22. https://doi.org/10.14361/transcript.9783839411797

Klüger, R. (1992), Weiter leben (Göttingen, Wallstein). 
Knowles, A.K., Cole, T. \& Giordano, A. (eds) (2014), Geographies of the Holocaust (Bloomington, IN, Indiana University Press).

Košir, U. (2017), 'Sounds of Horror. Sensorial Experiences of a Gestapo Prison, Begunje (Slovenia)', in N. Saunders \& P. Cornish (eds), Modern Conflict and the Senses (London, Routledge), 256-71. https://doi.org/10.4324/9781315682228-18

Kraft, R.N. (2004), 'Emotional Memory in Survivors of the Holocaust: A Qualitative Study of Oral Testimony', in D. Reisberg \& P. Hertel (eds), Memory and Emotion (Oxford, Oxford University Press), 347-89. https://doi.org/10.1093/acprof:oso/9780195158564.003.0011

Kret, J. (1959), 'Ein Tag in der Strafkompanie (Erinnerung)', Hefte von Auschwitz, 1: 87-124.

Kreutz, W. \& Strobel, K. (2018), Der Kommandant und die Bibelforscherin: Rudolf Höß und Sophie Stippel (Mannheim, Marchivum).

Kubica, H. (2015), From the Warsaw Uprising to Auschwitz (Oświęcim, Auschwitz-Birkenau State Museum).

Lachendro, J. (2016), Soviet Prisoners of War in Auschwitz (Oświęcim, Auschwitz-Birkenau State Museum).

Lang, J. (2010), 'Questioning Dehumanization: Intersubjective Dimensions of Violence in the Nazi Concentration and Death Camps', Holocaust and Genocide Studies, 24: 225-46. https://doi.org/10.1093/hgs/dcq026

Lang, J. (2018), 'The Proud Executioner-Pride and the Psychology of Genocide', in T. Brudholm \& J. Lang (eds), Emotions and Mass Atrocity (Cambridge, Cambridge University Press), 64-80. https://doi.org/10.1017/9781316563281.004

Langbein, H. (1995), Menschen in Auschwitz (München, Europa).

Lash, S. (2018), Experience: New Foundations for the Human Sciences (Cambridge, Polity Press).

Levi, P. (1987), If this is a Man/The Truce (London, Abacus).

Levi, P. (1989), The Drowned and the Saved (London, Abacus).

Levi, P., with L. de Benedetti (2006), Auschwitz Report (London, Verso).

Lill, K. (1978), 'Erinnerungen', Hefte von Auschwitz, 16: 137-58.

Lower, W. (2012), 'Living Space', in P. Hayes \& J. K. Roth (eds), The Oxford Handbook of Holocaust Studies (Oxford, Oxford University Press), 310-25.

Lower, W. (2018), 'Holocaust Studies: The Spatial Turn', in S. Baranowski, A. Nolzen \& C. C. Szejnmann (eds), A Companion to Nazi Germany (Hoboken, NJ, Wiley-Blackwell), 565-80. https://doi.org/10.1002/9781118936894.ch34

Mah, H. (2008), 'The Predicament of Experience', Modern Intellectual History, 5: 97-119. https://doi.org/10.1017/S1479244307001552

Mailänder, E. (2015), Female SS Guards and Workaday Violence (East Lansing, MI, Michigan State University Press).

Megargee, G.P. (ed.) (2009, 2012), Encyclopedia of Camps and Ghettos 1933-1945, vol. 1/A and 1/B (Bloomington, IN, Indiana University Press).

Millu, L. (1999), Der Rauch über Birkenau (Frankfurt a. M., Fischer).

Neumann, B. (2010), Die Weltanschauung des Nazismus (Göttingen, Wallstein).

Niethammer, G. (1941), 'Beobachtungen über die Vogelwelt von Auschwitz (Ost-Oberschlesien)', Annalen des Naturhistorischen Museums in Wien, 52: 164-99.

Niethammer, G. (1942), 'Entenbeobachtungen in Ost-Oberschlesien', Berichte des Vereins Schlesischer Ornithologen, 27: 30-4.

Nyiszli, M. (2012), Auschwitz: A Doctor's Eyewitness Account (London, Penguin).

Pawełczyńska, A. (2001), Werte gegen Gewalt (Oświęcim, Verlag des staatlichen Museums Auschwitz-Birkenau).

Perz, B. \& Freund, F. (2004), 'Auschwitz neu?', Dachauer Hefte, 20: 58-70. 
Pickering, M. (1997), History, Experience and Cultural Studies (Houndmills, Macmillan). https://doi.org/10.1007/978-1-349-25951-9

Piętka, B. (2012), 'The fire brigade Kommando (Feuerwehrkommando) at KL Auschwitz', Auschwitz Studies, 26: 179-98.

Pilecki, W. (2012), The Auschwitz Volunteer: Beyond Bravery (Los Angeles, CA, Aquila Polonica).

Pingel. F. (1978), Häftlinge unter SS-Herrschaft (Hamburg, Hoffmann \& Campe).

Piper, F. (1970), 'Das Nebenlager "Neu-Dachs”, Hefte von Auschwitz, 12: 55-112.

Piper, F. (1993), Die Zahl der Opfer von Auschwitz (Oświęcim, Verlag Staatliches Museum in Oświęcim).

Piper, F. (1995), Arbeitseinsatz der Häftlinge aus dem KL Auschwitz (Oświęcim, Verlag Staatliches Museum in Oświęcim).

Piper, F. (2000), 'Mass Murder', in W. Długoborski \& F. Piper (eds), Auschwitz. 1940-1945 (Oświęcim, Auschwitz-Birkenau State Museum), vol. 3: 9-231.

Plamper, J. (2017), The History of Emotions (Oxford, Oxford University Press).

Porteous, D. (2006), 'Smellscape', in J. Drobnick (ed.), The Smell Culture Reader (Oxford, Berg), 89-106.

Pozner, V. (1985), Abstieg in die Hölle (Berlin, Volk und Welt).

Pressac, J.-C. (1995), Die Krematorien von Auschwitz (München, Piper).

Przyrembel, A. (2018), 'Emotions and National Socialism', in S. Baranowski \& A. Nolzen \& C.C. Szejnman (eds), A Companion to Nazi Germany (Hoboken, NJ, Wiley Blackwell), 399-412. https://doi.org/10.1002/9781118936894.ch24

Rau, S. (2017), Räume, 2nd edn (Frankfurt a. M., Campus).

Reddy, W. (2001), The Navigation of Feeling: A Framework for the History of Emotions (Cambridge, Cambridge University Press). https://doi.org/10.1017/CBO9780511512001

Rindisbacher, H.J. (2006), 'The Stench of Power', in J. Drobnick (ed.), The Smell Culture Reader (Oxford, Berg), 137-47.

Rosenwein, B.H. (2002), 'Worrying about Emotions in History', The American Historical Review, 107: 821-45. https://doi.org/10.1086/532498

Rosenwein, B.H. (2010), 'Problems and Methods in the History of Emotions', Passions in Context, 1: $1-32$

Roth, K.-H . (1993), ““Generalplan Ost” - “Gesamtplan Ost”, in M. Rössler \& S. Schleiermacher (eds), Der 'Generalplan Ost' (Berlin, Akademie Verlag), 25-95.

Ryn, Z. \& Kłodziński, S. (1994), "Eine Studie über die Erscheinung des "Muselmanns" im Konzentrationslager', in Hamburger Institut für Sozialforschung (ed.), Die Auschwitz-Hefte (Hamburg, Roger \& Bernhard), vol. 1: 89-154.

Sachnowitz, H. (1981), Auschwitz. Ein norwegischer Jude überlebte (Frankfurt a. M., Büchergilde Gutenberg).

Samuel, R. (2016), 'People's History', in R. Samuel (ed.), People's History and Socialist Theory (London, Routledge), xiv-xxxix. https://doi.org/10.4324/9781315617091

Schafer, R.M. (1994), Soundscape: Our Sonic Environment and the Tuning of the World (Rochester, Destiny Books).

Scheer, M. (2012), 'Are Emotions a Kind of Practice (And is That What Makes Them Have a History)? A Bourdieuian Approach to Understanding Emotion', History and Theory, 51: 193-220. https://doi.org/10.1111/j.1468-2303.2012.00621.x

Schuessler, J. (2016), “The Evidence Room”: Architects Examine the Horrors of Auschwitz', The New York Times, 14 June 2016.

Schulte, J.E. (2001), Zwangsarbeit und Vernichtung: Das Wirtschaftsimperium der SS (Paderborn, Schöningh).

Scott, J.W. (1991), 'Evidence of Experience', Critical Inquiry, 17: 773-97. https://doi.org/10.1086/448612 
Setkiewicz, P. (2008), 'The Fencing and System of Preventing Prisoner Escapes at Auschwitz Concentration Camp', in T. Świebocka (ed.), The Security and Isolation System of the Auschwitz Camp (Oświęcim, Auschwitz-Birkenau State Museum), 13-56.

Setkiewicz, P. (2018a), The SS Garrison in KL Auschwitz (Oświęcim, Auschwitz-Birkenau State Museum). Setkiewicz, P. (2018b), 'The First Jews in KL Auschwitz', Auschwitz Studies, 29: 7-48.

Shelley, L. (ed.) (1991), Criminal Experiments on Human Beings in Auschwitz and War Research Laboratories (San Francisco, CA, Mellen Research University Press).

Shelley, L. (ed.) (1992), Schreiberinnen des Todes (Bielefeld, AJZ Verlag).

Shelley, L. (ed.) (1996), The Union Kommando in Auschwitz (Lanham, MD, University Press of America).

Siedlecki, J.N., Olszewski, K. \& Borowski, T. (2000), We Were in Auschwitz (New York, Welcome Rain Publishers), first published in Polish in 1946.

Smith, M.M. (2007), Sensing the Past (Berkeley, CA, University of California Press).

Sobolewicz, T. (1993), Aus dem Jenseits zurück (Oświęcim, Auschwitz-Birkenau State Museum).

Sofsky, W. (1997), Die Ordnung des Terrors (Frankfurt a. M., Fischer).

Sonnino, P. (2006), Die Nacht von Auschwitz (Reinbek, Rowohlt).

Spritzer, J. (1994), Ich war Nr. 10291 (Stäfa, Rothenhäusler Verlag).

Stearns, P.N. \& Stearns, C.Z. (1985), 'Emotionology: Clarifying the History of Emotions and Emotional Standards', The American Historical Review, 90: 813-36. https://doi.org/10.2307/1858841

Steinbacher, S. (2000), 'Musterstadt' Auschwitz (München, K.G. Saur). https://doi.org/10.1515/9783110958317

Steinbacher, S. (2005), Auschwitz. A History (London, Penguin). https://doi.org/10.17104/9783406676284

Stewart, S. (2005), 'Remembering the Senses', in D. Howes (ed.), Empire of the Senses (Oxford, Berg), $59-69$.

Stone, D. (2016), 'Holocaust Spaces', in P. Giaccaria \& C. Minca, C. (eds), Hitler's Geographies (Chicago, IL, University of Chicago Press), 45-62.

Strzelecka, I. (1990), 'Die ersten Polen im KL Auschwitz', Hefte von Auschwitz, 18: 5-146.

Strzelecka, I. (2002), 'Männerlager in Birkenau (BIId) Juli 1943 bis Januar 1945', Hefte von Auschwitz, 22: $149-342$.

Strzelecka, I. (2009), 'Das Frauenlager im KL AuschwitzBirkenau (BIa, BIb)', Hefte von Auschwitz, 24: $7-124$.

Strzelecka, I. (2012), 'Frauen in den Durchgangslagern im KL Auschwitz II-Birkenau', Hefte von Auschwitz, 25: 65-124.

Strzelecka, I. \& Setkiewicz, P. (2000), 'The Construction, Expansion and Development of the Camp and its Branches', in W. Długoborski \& F. Piper (eds), Auschwitz. 1940-1945 (Oświęcim, AuschwitzBirkenau State Museum), vol. 1: 63-138.

Sturdy Colls, C. (2015), Holocaust Archaeologies: Approaches and Future Directions (New York, Springer). https://doi.org/10.1007/978-3-319-10641-0

Süss, D. (2014), Death from the Skies: How the British and Germans Survived Bombing in World War II (Oxford, Oxford University Press).

Świebocka, T. (ed) (2001), The 'Central Camp Sauna' in Auschwitz II-Birkenau (Oświęcim, AuschwitzBirkenau State Museum).

Świebocki, H. (2000), 'The Resistance Movement', in W. Długoborski \& F. Piper (eds), Auschwitz. 19401945 (Oświęcim, Auschwitz-Birkenau State Museum), vol. 4: 13-330.

Szmaglewska, S. (2008), Smoke over Birkenau (Oświęcim, Auschwitz-Birkenau State Museum), first published in Polish in 1945.

Tanenbaum, R. (1998), Prisoner 88 (Calgary, University of Calgary Press). 
Theune, C. (2010), 'Historical Archaeology in National Socialist Concentration Camps in Central Europe', Historische Archäologie, 2: 1-14. https://doi.org/10.1007/978-3-319-51726-1_1786-2

Theune, C. (2018), 'Clothes as Expression of Action in Former Concentration Camps', International Journal of Historical Archaeology, 22: 492-510. https://doi.org/10.1007/s10761-017-0440-3

Tietjen, J.M. (2016), “'Unbearable Stench”: Excremental Violence in Holocaust Literature' (PhD dissertation, Brandeis University).

Trial of the Major War Criminals before the International Military Tribunal (1948), vol. 29 (Nuremberg, IMT).

van Pelt, R.J. (2002), The Case for Auschwitz (Bloomington, IN, Indiana University Press).

Venezia, S. (2009), Inside the Gas Chambers (Cambridge, Polity Press).

Wachsmann, N. (2015), KL: A History of the Nazi Concentration Camps (New York, Farrar, Straus and Giroux).

Wachsmann, N. (2020), 'Being in Auschwitz: Lived Experience and the Holocaust', Times Literary Supplement, 24 January 2020, 9-11.

Winter, W. (2004), Winter Time: Memoirs of a German Sinto Who Survived Auschwitz (Hatfield, University of Hertfordshire Press).

Wolf, M. (ed.) (2016), Interpreting in Nazi Concentration Camps (New York, Bloomsbury).

Zywulska, K. (2011), I Survived Auschwitz (Warszawa, tCHu), first published in Polish in 1946.

To cite the article: Nikolaus Wachsmann (2021), 'Lived experience and the Holocaust: spaces, senses and emotions in Auschwitz', Journal of the British Academy, 9: 27-58. DOI https://doi.org/10.5871/jba/009.027

Journal of the British Academy (ISSN 2052-7217) is published by The British Academy, 10-11 Carlton House Terrace, London, SW1Y 5AH www.thebritishacademy.ac.uk 